\title{
REACHING ACROSS THE DITCH? SIMILARITIES AND DIFFERENCES IN THE TRAJECTORY OF AUSTRALIAN AND NEW ZEALAND REGULATION OF COLLECTIVE LABOUR RELATIONS 1988-2018
}

\author{
Anthony Forsyth ${ }^{*}$ and John Howe ${ }^{* *}$
}

\begin{abstract}
This article compares the development of the law and policy relating to collective aspects of labour relations in Australia and New Zealand over the last 30 years, taking account of historical, social, economic and political context. During that period, there have been many shifts and turns in the direction of regulation, although developments in each country have mostly responded to the broader rise of neo-liberalism in economic and social policy. In this article we examine the differing workplace reform agendas of Labor/Labour and Coalition/National governments in these two countries, alongside the competing policy objectives of these reforms (deregulatory versus protective), and assess the extent to which these reforms have encouraged, undermined, or reflected a position of "state neutrality" toward collective bargaining. In making this assessment, we reflect on similarities and differences in the trajectory of Australian and New Zealand regulation of collective labour relations, and the level of influence that developments in each country has had on the other.
\end{abstract}

\section{OVERVIEW}

Australian and New Zealand labour law share common historical origins and followed a somewhat similar path of development over much of the 20th century. As noted in Richard Mitchell's article in this special issue, comparison of the evolution of the two systems has been a focus of Gordon Anderson's scholarship. This article focuses on the trajectory of collective labour regulation in

* $\quad$ Professor, Graduate School of Business \& Law, RMIT University, Melbourne.

** Professor and Director, Melbourne School of Government, University of Melbourne. We would like to thank Ruby Bell and Melissa Kennedy for their research assistance. 
Australia and New Zealand over the most recent 30-year period, tracing similarities and differences between the two countries and noting that these trajectories have been framed by broader neo-liberal tendencies. Both countries witnessed successive rounds of labour law reforms between 1988 and 2018, pushing away from their traditional protective purposes in favour of increasingly deregulatory changes, with the pendulum eventually swinging back to ostensibly collectivist laws more recently. Both nations also experienced "big bang" legislative change seeking to entrench an individualistic approach to employment relations - in New Zealand, the Employment Contracts Act 1991, and in Australia, the Workplace Relations Amendment (Work Choices) Act 2005 (Work Choices legislation $)^{1}$ - although, we contend, with different long-term effects. In the Australian context, we focus on federal developments, rather than the evolution of state labour law systems (although it should be noted that New Zealand's deregulatory legislation had a strong influence over the reform agendas in Victoria and Western Australia in the early 1990s). ${ }^{2}$

This article explores the shifting contours of the reform process in each country over the last 30 years by examining (in comparative perspective) three specific aspects of legal support for collective bargaining: provisions which ensure recognition of trade unions and union involvement in collective agreement negotiations; the rules applicable to the bargaining process including "good faith bargaining" obligations; and the availability of industrial action to support collective bargaining claims. These three elements have been chosen because they tell us much about the extent to which a labour law system exhibits a strong preference in favour of collective bargaining - or, on the other hand, whether a position of "state neutrality" has been adopted, through rules which are merely facilitative but indifferent about bargaining actually taking place. ${ }^{3}$ We assess the development of collective labour law in Australia and New Zealand in these terms in Part IV of the article and draw together some other principal observations from our comparison of the two systems which is found in Part III. Before that, in Part II, we provide a brief overview of the major twists and turns in collective labour regulation in the two countries over the last 30 years.

1 Workplace Relations Amendment (Work Choices) Act 2005 (Cth).

2 See for example Breen Creighton "Employment Agreements and Conditions of Employment under the Employee Relations Act 1992 (Vic)" (1993) 6 AJLL 140.

3 See Ruth Dukes "The Statutory Recognition Procedure 1999: No Bias in Favour of Recognition?" (2008) 37 ILJ 236; Alan Bogg The Democratic Aspects of Trade Union Recognition (Hart Publishing, Oxford, 2009); Benjamin Sachs "Enabling Employee Choice: A Structural Approach to the Rules of Union Organising" (2010) 123 Harv L Rev 655; and Gregor Gall "Statutory Union Recognition Provisions as Stimulants to Employer Anti-Unionism in Three Anglo-Saxon Countries" (2010) 31 Economic and Industrial Democracy 7. 


\section{CHANGE TO COLLECTIVE LABOUR LAW IN AUSTRALIA AND NEW ZEALAND WITHIN THE NEO-LIBERAL AGENDA}

A key feature of Gordon Anderson's scholarship in general, but particularly his work comparing New Zealand and Australia, has been the recognition that labour law is not a set of static, neutral and autonomous rules pertaining to work, but is instead an evolving system shaped by historical factors, and subject to social, economic and political context. ${ }^{4}$ From the mid-1980s, both Australia and New Zealand have significantly departed from their traditional labour law systems based on compulsory conciliation and arbitration and the setting of employment conditions through awards. The drivers in each case were similar. Broader economic reform programmes in each country led to significant pressure for labour market deregulation because: "[h]igh labour costs (and the tightly regulated economy needed to protect those labour costs) made goods and services unmarketable in a globalising economy." ${ }^{5}$ In Australia, demands for reform were pushed by the HR Nicholls Society and key figures in the conservative opposition parties, ${ }^{6}$ while in New Zealand it was the New Zealand Business Roundtable, ${ }^{7}$ but all were influenced by the neo-liberal "New Right" agenda then gathering pace globally. In each case, the Labor/Labour Governments then in power sought to introduce greater flexibility within the existing arbitral frameworks through enterprise-based bargaining.

New Zealand's Labour Relations Act 1987 did not satisfy the reform appetite of those seeking greater deregulation, leading to the more radical shift in the Employment Contracts Act introduced by a National Government. ${ }^{8}$ This legislation was "the conscious and inevitable expression of the neoliberal conviction that self-interested, individual choices are the basis for optimal market functioning". ${ }^{9}$ It is also important to note that until 1996, New Zealand had a "first past the post"

4 See for example Gordon Anderson Reconstructing New Zealand's Labour Law: Consensus or Divergence? (Victoria University Press, Wellington, 2011) at 16. For more on this contextualised approach to labour law scholarship, see also Paul Davies and Mark Freedland Labour Legislation and Policy (Clarendon Press, Oxford, 1993); and Bob Hepple (ed) The Making of Labour Law in Europe: A Comparative Study of Nine Countries up to 1945 (Mansell, London, 1986).

5 Dennis Nolan "Examining the Australasian Labour Law Reforms" in Dennis Nolan (ed) The Australasian Labour Law Reforms: Australia and New Zealand at the End of the Twentieth Century (The Federation Press, Sydney, 1998) 1 at 2.

6 See for example HR Nicholls Society Arbitration in Contempt (HR Nicholls Society, Melbourne, 1986).

7 Anderson Reconstructing New Zealand's Labour Law, above n 4, at 57. See further Penelope Brook Freedom at Work: The Case for Reforming Labour Law in New Zealand (Oxford University Press, Auckland, 1990).

8 Anderson Reconstructing New Zealand's Labour Law, above n 4, at 57-58; and Gordon Anderson and Michael Quinlan "The Changing Role of the State: Regulating Work in Australia and New Zealand 17882007" (2009) 95 Labour History 111 at 124-125.

9 Pam Nuttall "Collective Bargaining and Good Faith Obligations in New Zealand" in Breen Creighton and Anthony Forsyth (eds) Rediscovering Collective Bargaining: Australia's Fair Work Act in International Perspective (Routledge, Abingdon-on-Thames (UK), 2012) 290 at 294. 
electoral system, which in the context of a unicameral parliament, meant that the party winning power faced few limitations in enacting major legislative changes. In Australia, the initial development of enterprise bargaining had a longer gestation period, effected first through a major decision of the federal industrial tribunal in $1991^{10}$ and then through legislative amendments in 1992 and $1993 .^{11}$ Although the conservative Howard Coalition Government elected in 1996 aspired to radical industrial relations reform like the New Zealand Employment Contracts Act, Australia's bicameral Parliament and preferential voting system made the achievement of a radical legislative agenda more difficult. ${ }^{12}$ More drastic, New Zealand-style reform did not occur until the 2005 Work Choices legislation, after the Government gained control of both houses of Parliament, ${ }^{13}$ presaged by earlier reforms which had (among other things) diluted union influence over the bargaining process. ${ }^{14}$

The periods of individualist-oriented reform were ended, in both countries, by a swing back to a more collectivist ethos: in New Zealand, through the Labour Government's Employment Relations Act 2000, and in Australia under Labor's Fair Work Act 2009. However, it has been contended that in both instances, the extent of restoration of collectivism in labour relations was limited or attenuated. ${ }^{15}$ It is certainly true that both of these "leftist" governments were seeking to balance the restoration of workplace protections for employees with the objective of retaining some scope for employer flexibility. ${ }^{16}$ It is perhaps this balance that has prevented subsequent conservative governments in both New Zealand and Australia from implementing any further dramatic reforms to collective labour relations. In the case of New Zealand, it may also have been that further reforms were not necessary, given that the negative impact of the Employment Contracts Act on collectivism seems to have been far greater than the impact of the Work Choices legislation in Australia. Nevertheless, the New Zealand National Government in power between 2008 and 2017 did introduce a number of measures designed to undermine collective bargaining, some of which are likely to be rolled back by the Ardern Labour Government. In Australia, the Abbott and Turnbull Coalition

10 National Wage Case - October 1991 (1991) 39 IR 127 (AIRC).

11 Industrial Relations Legislation Amendment Act 1992 (Cth); and Industrial Relations Reform Act 1993 (Cth).

12 See Andrew Stewart and others Creighton and Stewart's Labour Law (6th ed, The Federation Press, Sydney, 2016) at 65-66; and Gordon Anderson and others "The Evolution of Labor Law in New Zealand: A Comparative Study of New Zealand, Australia and Five Other Countries" (2011) 33 Comp Lab L \& Pol'y J 137.

13 Workplace Relations Amendment (Work Choices) Act.

14 Workplace Relations and Other Legislation Amendment Act 1996 (Cth).

15 Anderson and Quinlan "The Changing Role of the State", above n 8, at 125-26; and Breen Creighton "A Retreat from Individualism? The Fair Work Act 2009 and the Re-Collectivisation of Australian Labour Law" (2011) 40 ILJ 116.

16 Anderson Reconstructing New Zealand's Labour Law, above n 4, at 133; and Andrew Stewart "A Question of Balance: Labor's New Vision for Workplace Regulation" (2009) 22 AJLL 3. 
Governments pursued only piecemeal changes to the collective bargaining provisions in the Fair Work Act, for reasons explored below.

\section{COMPARING KEY ELEMENTS OF NEW ZEALAND AND AUSTRALIAN COLLECTIVE LABOUR LAW}

\section{A Union Recognition and Involvement of Unions in Bargaining}

Statutory union recognition processes of the kind found in the North American and United Kingdom labour law systems, were not required under the traditional conciliation and arbitration frameworks of New Zealand and Australia. That was because the compulsory nature of the processes for making awards (setting minimum wages and other employment conditions) operated as a "de facto" form of recognition: employers were legally required to participate in those processes once unions invoked them. ${ }^{17}$ Further, in both countries, registered unions were built into the "fabric" of the conciliation and arbitration architecture, with extensive support for their representational and organisational activities (although there were also significant legal controls, for example in relation to industrial action). ${ }^{18}$ However, the shift towards enterprise-based collective bargaining systems in New Zealand and Australia from the late 1980s presented the issue of how employers could be compelled to engage in bargaining, if at all, with varying approaches taken in both countries' laws in the period since then.

\section{New Zealand}

Unions retained the central position they had occupied in the traditional system as New Zealand made its tentative moves towards enterprise bargaining under the 1987 Labour Relations Act. ${ }^{19}$ However this approach was short-lived, as the Employment Contracts Act completely dismantled state support for collective bargaining and the role of unions. It provided for the negotiation of individual employment contracts between an employer and an employee, and also for collective employment contracts, with employees having the option to negotiate directly or through "bargaining agents". ${ }^{20}$ However, "there was no mention in the legislation of unions and no mechanism to establish any form of enterprise collective arrangements through majority choice". ${ }^{21}$ Combined with its

17 Gordon Anderson Labour's Labour Law: Labour Law Reform in New Zealand Under a Labour Government, (Institute of Employment Rights, London, 2001) at 6; and Anthony Forsyth Tradition and Change in Australian Labour Law (Institute of Employment Rights, London, 1998) at 14.

18 Dennis Nolan "RIP: Compulsory Labour Arbitration in New Zealand, 1894-1984" (1991) 12 Comp Lab LJ 411 at 417-418, 423-424 and 431; and Stewart and others, above n 12, at 814-816.

19 Anderson Reconstructing New Zealand's Labour Law, above n 4, at 59-60.

20 Margaret Wilson "Labour Law Reform: Context and Foundations" in Dennis Nolan (ed) The Australasian Labour Law Reforms: Australia and New Zealand at the End of the Twentieth Century (The Federation Press, Sydney, 1998) 5 at 13.

21 Nuttall, above n 9, at 291. 
abolition of the almost century-old conciliation and arbitration system, ${ }^{22}$ the 1991 legislation reconstructed New Zealand employment relations on the basis of the common law contract of employment - a triumph of individualist free market philosophy. Its impact was profound: a fall of over 40 per cent in collective bargaining density between 1989-90 and 1996, and a more than halving of union membership density between 1985 and $1995 .^{23}$

The Labour Government's modification of this contractualist experiment, through the Employment Relations Act, sought to rebuild collectivism in New Zealand labour relations, although without any compulsion upon employers to engage in collective bargaining. Unions obtained a monopoly over the bargaining process in that a collective agreement was required to be negotiated with a union, and only union members were covered by the agreement once it was made. ${ }^{24}$ This was based on the principle "join the union, join the agreement". ${ }^{25}$ A major feature of the 2000 legislation was its foundation upon the concept of good faith in all aspects of employment relations, including collective bargaining. ${ }^{26}$ Nuttall contends that the measures in the 2000 statute aimed at restoring collective bargaining were premised on optimistic assumptions about the transformative effect of good faith principles, and that they: ${ }^{27}$

... have been insufficient to displace the legacy of the [Employment Contracts Act]: individualised workplace arrangements, private ordering of employment relationships and power structures governed by the presumptions of managerial prerogative.

This is borne out by the fact that collective agreement coverage fell even further to 19.1 per cent of the workforce by 2008, as Blumenfeld pointedly observes, "after nine years under legislation that purportedly supported collective bargaining". 28

It is a measure of the continuing impact of the Employment Contracts Act that the National Government which took office in 2008 did not implement extensive changes to the bargaining

22 At 291

23 Raymond Harbridge and Aaron Crawford "New Zealand Labour Law Reform: Consequences and Prospects" in Dennis Nolan (ed) The Australasian Labour Law Reforms: Australia and New Zealand at the End of the Twentieth Century (The Federation Press, Sydney, 1998) 207 at 211-214.

24 Richard Naughton The Shaping of Labour Legislation: Underlying Elements of Australia's Workplace Relations System (LexisNexis Butterworths, Chatswood (NSW), 2017) at 361-362. Chapter 10 of Naughton's text is devoted to the New Zealand labour law system.

25 Anderson Reconstructing New Zealand's Labour Law, above n 4, at 22.

26 Naughton, above n 24, at 360.

27 Nuttall, above n 9, at 292.

28 Stephen Blumenfeld "Collective bargaining" in Erling Rasmussen (ed) Employment Relationships: Workers, Unions and Employers in New Zealand (2nd ed, Auckland University Press, Auckland, 2010) 40 at 43. 
framework Labour had introduced through the 2000 legislation. ${ }^{29}$ National's amendments in 2014 were mostly directed at winding back aspects of the good faith bargaining obligations and restricting strikes. ${ }^{30}$ The Labour Government elected in late 2017 restored some of these bargaining rights through the Employment Relations Amendment Act 2018. However, 30 years after the introduction of enterprise bargaining in New Zealand, there is still no provision akin to a union recognition procedure compelling the commencement of collective agreement negotiations (and no proposal to introduce one).

\section{Australia}

In Australia, the shift to enterprise bargaining from the early 1990s also incorporated a central role for unions, at least initially. Under the 1992 legislative changes "certified agreements" could only be made between an employer and a union. ${ }^{31}$ The more elaborate system of enterprise bargaining introduced by the Industrial Relations Reform Act 1993 also provided for union-negotiated agreements, but opened up the option for employers to enter into "enterprise flexibility agreements" directly with groups of employees and without union involvement. ${ }^{32}$ No obligation was imposed upon employers to enter into collective agreement negotiations, and there was no formal union recognition process. Once bargaining commenced, good faith bargaining obligations applied to employer and union negotiators and unions could take "protected industrial action" in support of their claims. ${ }^{33}$ With the election of a Coalition Government came a progressive loosening of unions' hold on collective bargaining: first, through the 1996 reform legislation which created the option for employers of entering into statutory individual agreements with employees; then, under the Work Choices legislation, enabling those individual agreements to undermine collectively-negotiated conditions $^{34}$ and allowing non-union bargaining agents to represent employees in negotiations for individual and collective agreements. ${ }^{35}$

29 Gordon Anderson "The Sky Didn't Fall In: An Emerging Consensus on the Shape of New Zealand Labour Law?" (2010) 23 AJLL 94.

30 Employment Relations Amendment Act 2014.

31 Ron McCallum "Enhancing Federal Enterprise Bargaining: The Industrial Relations (Legislation Amendment) Act 1992 (Cth)" (1993) 6 AJLL 63.

32 Richard Naughton "The New Bargaining Regime Under the Industrial Relations Reform Act" (1994) 7 AJLL 147.

33 Naughton, above n 32. See also Greg McCarry "Sanctions and Industrial Action: The Impact of the Industrial Relations Reform Act" (1994) 7 AJLL 198.

34 Joel Fetter "Work Choices and Australian Workplace Agreements" (2006) 19 AJLL 210.

35 Anthony Forsyth and Carolyn Sutherland "Collective Labour Relations Under Siege: The Work Choices Legislation and Collective Bargaining" (2006) 19 AJLL 183 at 188. 
The period of Coalition rule (1996-2007) saw many major Australian employers (for example in mining, telecommunications and banking) utilise the legal framework to embark on strategies of deunionisation and individualisation. ${ }^{36}$ For unions, a major concern which they wanted the incoming Labor Government to rectify was the absence of any legal obligation on employers to engage in collective bargaining. This led to the inclusion of provisions in the Fair Work Act enabling employee bargaining representatives to apply to the tribunal for a "majority support determination" compelling an employer to bargain: the closest that the Australian and New Zealand systems have come to adopting a North American-style union recognition procedure. Indeed, the Australian proxy for union recognition improves upon its United States and Canadian forebears and the United Kingdom's statutory recognition procedure. ${ }^{37}$ Majority support determinations are not primarily reliant on union success in a workplace ballot to establish bargaining rights. Rather, the necessary majority support among the workforce can be proven in most cases on the basis of petitions of employees, thus avoiding the opportunities for hostile employer campaigns against union recognition which have plagued the North American and United Kingdom bargaining regimes. ${ }^{38}$

Other features of the Australian collective bargaining framework contrast quite sharply with New Zealand's provision of monopoly union rights in bargaining. Under the Fair Work Act, most enterprise agreements are made between employers and employees ${ }^{39}$ - unions are not parties principal to those agreements. Unions are the default bargaining representatives of those employees to be covered by an agreement who are union members. However, other employee bargaining representatives may be involved in agreement negotiations such as self-appointed individuals and those appointed by a group of employees. ${ }^{40} \mathrm{~A}$ union which has acted as a bargaining representative has the right to be "covered" by the agreement, which gives the union certain enforcement rights. Agreements, once in operation, cover all employees in the workplace performing work of a kind which is subject to the agreement. This creates a "free rider" problem for unions in that non-members obtain the benefit of union-

36 Rae Cooper and others "Anti-unionism, Employer Strategy, and the Australian State, 1996-2005" (2009) 34 Labor Studies Journal 339.

37 See for example Anthony Forsyth and others "Establishing the Right to Bargain Collectively in Australia and the UK: Are Majority Support Determinations under Australia's Fair Work Act a More Effective Form of Union Recognition?" (2017) 46 ILJ 335.

38 Anthony Forsyth and Bradon Ellem "Has the Australian Model Resisted US-Style Anti-Union Organising Campaigns? Case Studies of the Cochlear and ResMed Bargaining Disputes" in Shae McCrystal, Breen Creighton and Anthony Forsyth (eds) Collective Bargaining under the Fair Work Act (The Federation Press, Sydney, 2018) 45.

39 Naughton, above n 24, at 213. Except "greenfields" agreements for new business projects or ventures, which must be made between an employer and a union or unions with coverage rights over the relevant employees.

40 Stewart and others, above n 12, at 878-882. 
negotiated wages and conditions (and unions are prohibited from charging bargaining fees to nonmembers). ${ }^{41}$

As in New Zealand, the conservative Government which replaced Labor in 2013 has not undertaken far-reaching workplace law reform, largely because the spectre of the Coalition's deeply unpopular Work Choices legislation looms large over the policy debate. While a Productivity Commission review commissioned by the Government recommended changes to make the collective bargaining framework more employer-friendly, ${ }^{42}$ those recommendations have not been implemented. The Government has instead focused most of its attention on ratcheting up the financial accountability and transparency requirements applicable to union office holders, in the wake of several corruption scandals and the Royal Commission into Trade Union Governance and Corruption. ${ }^{43}$ Therefore, the collective bargaining framework introduced by Labor in 2009 remains largely intact. Although essentially intended to promote collectivism, over the period that the Fair Work Act has been in operation, collective agreement coverage has declined, ${ }^{44}$ although not as precipitously as in New Zealand. Attributing this outcome to several deficiencies in the legislation which employers have been able to exploit, the Australian Council of Trade Unions (ACTU) has campaigned since March 2017 for significant reforms which it wanted an incoming Labor Government to implement - such as the ability to bargain across industries, supply chains and franchise networks. ${ }^{45}$ However as Labor unexpectedly lost the May 2019 federal election, these changes will not be implemented.

\section{B The Bargaining Process}

While traditionally neither Australian nor New Zealand labour law made provision for North American-style good faith bargaining requirements, these have become a key feature of the collective bargaining systems of both countries under reforms introduced by Labor/Labour governments. The nature of the good faith obligations imposed by New Zealand and Australian law has been similar in several respects, with some important variations. Interestingly, measures intended to enforce good faith bargaining requirements through the spectre of an arbitrated outcome have been greatly underutilised in both systems.

41 At 380 .

42 Productivity Commission Workplace Relations Framework: Productivity Commission Inquiry Report (No 76, 30 November 2015).

43 Anthony Forsyth "Law, Politics and Ideology: The Regulatory Response to Trade Union Corruption in Australia" (2017) 40 UNSWLJ 1336.

44 From 43.4 per cent of the workforce in 2010 to 36.4 per cent in 2016: David Peetz and Serena Yu Explaining Recent Trends in Collective Bargaining (Fair Work Commission, Research Report 4/2017, February 2017).

45 See for example Sally McManus, Secretary of the Australian Council of Trade Unions "Change the Rules; For More Secure Jobs and Fair Pay" (speech to National Press Club, Canberra, 21 March 2018). 


\section{New Zealand}

New Zealand has lurched from the extreme position of providing no direction as to the collective bargaining process under the Employment Contracts Act, to establishing (arguably) a firmer foundation for good faith bargaining than Australia under the Employment Relations Act. The original good faith requirements imposed on parties negotiating a collective agreement included agreeing on a process for effective bargaining; meeting each other from time to time; considering and responding to the other party's proposals; recognising the role and authority of the other party's representatives and not undermining that authority; and providing each other with all information reasonably necessary to substantiate claims or responses. However, parties were not required to enter into an agreement nor agree on any matter for inclusion in an agreement. ${ }^{46}$

Amendments were made to these provisions in $2004,{ }^{47}$ inserting a requirement that parties conclude a collective agreement unless there was a genuine reason not to (based on reasonable grounds). In 2014, the National Government reversed this change, restoring the original position that good faith does not connote a duty to finalise an agreement. ${ }^{48}$ Turning full circle, the current Labour Government has moved to restore the duty. ${ }^{49}$ This issue is significant, as an obligation to reach an agreement may help address a major deficiency emanating from the United States system of good faith bargaining: the adoption (particularly by employers) of "surface bargaining" tactics, i.e. strict compliance with the procedural rules without any intention of concluding an agreement. ${ }^{50}$

Labour's 2004 amendments also addressed a matter arising from the 2000 legislation's creation of "member only" collective agreements: the problem of employers "passing on" agreement benefits to non-union members. Under the amendments, it is a breach of good faith if an employer passes on terms the same or substantially the same as terms of a collective agreement - but only where the passing on was done with intent to, and did, undermine the collective agreement. ${ }^{51}$ Further bolstering of the good faith bargaining obligations came through the 2004 amendments introducing penalties for

46 Anderson Labour's Labour Law, above n 17, at 22-24. The statutory good faith obligations were further articulated in a "Code of Good Faith for Bargaining for Collective Agreement".

47 Employment Relations Amendment Act 2014.

48 Naughton, above n 24, at 361-362. In 2010, National had also implemented an amendment to clarify that the good faith bargaining requirements did not prevent employers from communicating directly with employees during agreement negotiations: see Alex Bukarica and Andrew Dallas Good Faith Bargaining under the Fair Work Act 2009: Lessons from the Collective Bargaining Experience in Canada and New Zealand (The Federation Press, Sydney, 2012) at 79-86 (also discussing the relevant case law background).

49 Employment Relations Amendment Act 2018.

50 Bukarica and Dallas, above n 48, at 39-40.

51 Nuttall, above n 9, at 304. See also Andrew Caisley "Clarity or Confusion: The Employment Relations Amendment Act 2004 under the Lens" in Erling Rasmussen (ed) Employment Relationships: Workers, Unions and Employers in New Zealand (2nd ed, Auckland University Press, Auckland, 2010) 56 at 67-69. 
deliberate and serious breaches of those requirements, and powers for the Employment Relations Authority to address protracted negotiations through facilitation and (in extreme situations) fixing the terms of an agreement. ${ }^{52}$ Albeit very little utilised in practice, ${ }^{53}$ the effect of the fixing provisions was overridden by National's 2014 amendments. ${ }^{54}$

\section{Australia}

Australia's 1993 enterprise bargaining reforms introduced powers for the federal industrial tribunal to make orders ensuring that parties bargained in good faith, ${ }^{55}$ although these were interpreted as not requiring an employer to commence negotiations against its will. ${ }^{56}$ The Coalition's 1996 reform legislation repealed these good faith bargaining provisions, and attempts by the federal tribunal to read good faith principles back into the legislation were thwarted by the Work Choices legislation. ${ }^{57}$ In 2009, the Labour Government introduced more robust good faith bargaining rules than those applicable under the 1993 legislation. The content of the good faith requirements under the Fair Work Act $^{58}$ is similar to that found in New Zealand's 2000 legislation. At no point, however, has there been an Australian equivalent to the duty to conclude an agreement. Rather, the statutory insistence on the absence of such a duty has been reinforced by tribunal and court decisions precluding the imposition of good faith bargaining orders requiring an employer to table agreement proposals. ${ }^{59}$ In this way, the Australian system has proven less effective in addressing employer surface bargaining approaches than has been the case at various points in the evolution of the New Zealand good faith regime.

On the other hand, the Fair Work Act's prohibition on parties engaging in capricious or unfair conduct that undermines bargaining arguably goes further than the New Zealand rules in addressing certain forms of substantive bad faith conduct. For example, it has formed the basis for rulings preventing employers from making direct offers to employees represented by a union in bargaining or unilaterally altering employment conditions (even if this involves wage increases) during

52 Bukarica and Dallas, above n 48, at 76-78.

53 At $76-78$.

54 Naughton, above n 24, at 363.

55 Richard Naughton "Bargaining in Good Faith" in Paul Ronfeldt and Ron McCallum (eds) Enterprise Bargaining, Trade Unions and the Law (The Federation Press, Sydney, 1995) 84.

56 Asahi Diamond Industrial Australia Pty Ltd v Automotive Food Metals and Engineering Union (1995) 59 IR 385 (AIRC)

57 Forsyth and Sutherland, above n 35, at 194

58 See Stewart and others, above n 12, at 885-886.

59 See for example Endeavour Coal Pty Ltd v Association of Professional Engineers, Scientists and Managers, Australia [2012] FCA 764, (2012) 206 FCR 576; and Australian Manufacturing Workers' Union v Cochlear Ltd [2012] FWA 5374, (2012) 231 IR 1. 
negotiations. ${ }^{60}$ Finally, the Fair Work Act includes quite elaborate provisions to ensure compliance with the good faith requirements. These include bargaining orders, "serious breach declarations" to address egregious breaches of bargaining orders and (in extreme cases) "bargaining related workplace determinations" - a rough equivalent to the New Zealand provisions for fixing the terms of an agreement. However, this avenue to arbitration of an agreement as a remedy for serious bad faith conduct under the Australian legislation has never been used. ${ }^{61}$

\section{Industrial Action}

Industrial action was antithetical to the conciliation and arbitration models of industrial relations in Australia and New Zealand. Prior to 1987, there was no "right to strike" recognised in New Zealand. As observed by Justice Higgins, the second President of the Australian Court of Conciliation and Arbitration, under what he described as the new province for law and order': 62

... the process of conciliation with arbitration in the background is substituted for the rude and barbarous processes of strike and lockout. Reason is to displace force; the might of the State is to enforce peace between industrial combatants as well as between other combatants; and all in the interests of the public.

In both countries, statutory requirements for the system of compulsory arbitration and the operation of economic torts made almost all strikes unlawful. ${ }^{63}$ However, with the introduction of formal enterprise bargaining systems in each country, there was a recognition that the parties should be able to use industrial action as economic leverage in the negotiation of enterprise agreements.

\section{New Zealand}

A key element in the 1987 establishment of a formal enterprise bargaining system in New Zealand was the introduction of legal protection from civil action in the case of "lawful" strikes and lockouts - that is, industrial action taken in the context of enterprise bargaining. Industrial action not within this protected zone was "unlawful" and subject to remedies under the common law or the Labour Relations Act. Secondary strikes were permitted as long as they related to enterprise bargaining.

60 Finance Sector Union of Australia v Commonwealth Bank of Australia [2010] FWA 2690; and Australian Manufacturing Workers' Union v Galintel Rolling Mills Pty Ltd t/as The Graham Group [2011] FWA 6326.

61 Stewart and others, above n 12, at 887-892.

62 HB Higgins A New Province for Law and Order (Workers' Educational Association of New South Wales, Sydney, 1922) at 2.

63 Gordon Anderson, John Hughes and Dawn Duncan Employment Law in New Zealand (2nd ed, Lexis Nexis, Wellington 2017) at 530; and Gordon Anderson Labour Law in New Zealand (2nd ed, Wolters Kluwer, Alphen aan den Rijn (Netherlands), 2015) at 208. See also Gordon Anderson "The Reception of the Economic Torts into New Zealand Labour Law: A Preliminary Discussion" (1987) 12 NZJIR 89. 
This limited freedom to take industrial action in an enterprise bargaining context was considerably narrowed under the Employment Contracts Act. ${ }^{64}$ Under the policy of "enterprise confinement", 65 the legislation "restricted participation in a lawful strike to those employees whose employment would be covered by the collective agreement being bargained for". ${ }^{66}$ Strikes to obtain multi-employer contracts were unlawful, and secondary or sympathy action became unlawful "even if there was a close connection with those seeking support". ${ }^{67}$

The Employment Relations Act was a return to a somewhat wider protection, while maintaining the link with enterprise bargaining. Protection for industrial action taken in relation to bargaining over a "multi-employer collective agreement" was reinstated, as long as this was approved by union members in each of the workplaces to be covered. ${ }^{68}$ However the prohibition on secondary or sympathy strikes was retained. ${ }^{69}$

The Key National Government introduced amendments to the Employment Relations Act in 2012, mirroring the Australian requirement (introduced by the Work Choices legislation) that unions were to hold a secret ballot of members prior to taking industrial action, except where the action was being taken in relation to health and safety issues. ${ }^{70} \mathrm{~A}$ further amendment in 2014 requires that before lawful strike action can be taken, a strike notice must be provided to the employer and that partial strike action incurs deductions from wages, as is the case for full strike action. ${ }^{71}$

On paper, the creation of a limited freedom to take industrial action in New Zealand was an improvement on the pre-1987 legal position regarding strikes, largely moving the regulation of industrial conflict into the province of statutory law rather than the common law. However, the legislative changes just outlined reveal that the parameters of what constitutes lawful industrial action "[have] become more subject to political revision and change", ${ }^{72}$ with Labour governments reluctant to completely restore rights lost under conservative legislation. Moreover, in practice, there has been more willingness to use the law to police the boundaries of what constitutes lawful industrial action,

64 Anderson, Hughes and Duncan, above n 63, at 530.

65 Anderson Labour Law in New Zealand, above n 63, at 210; and Gordon Anderson Reconstructing New Zealand's Labour Law, above n 4, at 74.

66 Anderson Labour Law in New Zealand, above n 63, at 210.

67 Anderson Reconstructing New Zealand's Labour Law above n 4, at 75.

68 At 143.

69 At 144.

70 Margaret Wilson "Strike Ballots: The New Zealand Experience" (2016) 29 AJLL 194 at 203.

71 At 203.

72 Anderson, Hughes and Duncan, above n 63, at 530. 
in contrast to the situation prior to 1987, when it was less common for the law to be enforced against industrial action. ${ }^{73}$

\section{Australia}

As noted above, a prohibition on industrial action was a central component of Australian conciliation and arbitration - as the "new province for law and order", there was no need for strikes. However, in practice, industrial action was widespread, as the bans were generally not enforced. ${ }^{74}$ From the 1970s onwards, employers became more active in using the economic torts against strikes.

Australia's introduction of a limited statutory protection for industrial action taken in relation to enterprise bargaining trailed similar New Zealand developments by six years. As noted earlier, a formal statutory system of enterprise bargaining in Australia was only established in 1993, several years after the equivalent reforms in New Zealand. The Industrial Relations Reform Act provided for legal protection of industrial action against common law liability, and excluded the application of relevant statutory sanctions, provided that certain preconditions were satisfied. Lawful industrial action was "protected action". Protected industrial action was not available in the context of multiemployer bargaining, nor was it available in relation to secondary boycotts. ${ }^{75}$

The conservative Howard Government's Workplace Relations Act 1996 introduced some new restrictions on the scope of protected action and strengthened the sanctions available in relation to unlawful industrial action. ${ }^{76}$ Action taken before the nominal expiry date of an enterprise agreement became unlawful. The Act also introduced a new provision which gave the federal tribunal the power to order that any unprotected industrial action "cease or not occur". This provided employers with a relatively quick and inexpensive avenue for challenging industrial action, which they used to their advantage. ${ }^{77}$

With control of both houses of Parliament after 2004, the Howard Coalition Government moved quickly to further restrict the capacity of unions to place industrial pressure on employers. The Work Choices legislation tightened the scope of protected industrial action, and introduced a compulsory requirement that proposed industrial action be authorised by a secret ballot for the action to be

73 At 530 .

74 Breen Creighton "Enforcement in the Federal Industrial Relations System: An Australian Paradox" (1991) 4 AJLL 197.

75 Shae McCrystal The Right to Strike in Australia (The Federation Press, Sydney, 2010) at 77.

76 At 78 .

77 Anthony Forsyth "A New Handbrake on Industrial Action ... Or Not? A Note on Cases Relating to Section 127 of the Workplace Relations Act 1996 (Cth)" (1998) 11 AJLL 152. 
protected. ${ }^{78}$ The legislation also took away the federal tribunal's discretion in the making of orders in relation to unprotected action and widened the circumstances in which the tribunal could suspend enterprise bargaining and stop protected action.

The Rudd Labor Government's Fair Work Act retained the main elements of the Work Choices regime with respect to industrial action, most likely in an effort to placate employers and to reinforce the idea that a balanced approach was being taken. In particular, secret ballots have effectively become a permanent feature of the regime, ${ }^{79}$ as have the enforcement mechanisms against unlawful industrial action. However, one of the most significant developments in the scope of protected action under the Fair Work Act has been the Fair Work Commission's willingness to suspend or terminate protected industrial action that it has determined to be threatening to the life, personal safety or health, or the welfare of the population or part of it, under s 424 of the legislation. ${ }^{80}$ The tribunal's broad interpretation of when industrial action may threaten the "welfare" of the population, or part of it, has severely curtailed the capacity of many classes of workers to place any meaningful pressure on their employer, given that the very nature of industrial action is to cause some level of inconvenience or stress on individuals in order to achieve leverage in a bargaining context. ${ }^{81}$

As with New Zealand, the introduction of a limited right to strike has coincided with a significant decline in the actual incidence of industrial action. Stewart and others note that "[s]ince the introduction of these protections, levels of industrial disputation have plummeted", with the number of days lost to industrial action in the calendar year 2014 numbering 71,400, compared to 1.64 million days lost in $1988 .{ }^{82}$ This led to calls by the ACTU for a significant expansion in the right to strike under its "Change the Rules" campaign. ${ }^{83}$

\section{CONCLUSION}

Our examination in this article of the development of Australian and New Zealand regulation of collective labour regulation over the last 30 years, within the broader frame of the neo-liberal project

78 Shae McCrystal "Smothering the Right to Strike: Work Choices and Industrial Action" (2006) 19 AJLL 198 at 201.

79 See further Breen Creighton, Catrina Denvir and Shae McCrystal "Strike Ballots and the Law in Australia" (2016) 29 AJLL 154.

80 See for example Sydney Trains; NSW Trains; The Hon Dominic Perrottet, Minister for Industrial Relations (New South Wales) [2018] FWC 519.

81 Stewart and others, above n 12, at 996.

82 Stewart and others, above n 12, at 921-22, citing Australian Bureau of Statistics "6321.0.55.001 - Industrial Disputes, Australia, Dec 2015" (10 March 2016) <www.abs.gov.au>.

83 McManus, above n 45. 
pursued by Labour/Labor and Coalition/National governments, enables us to make the following general observations.

First, the replacement of industrial conciliation and arbitration with a collective enterprise bargaining system has been a key area of convergence between Australia and New Zealand, although the timeline of this trajectory in each country has differed. In both nations, this shift was initiated by governments of the left as part of economic reform programmes responding to the rising neo-liberal tide globally. In each case, the efforts of those governments to accommodate enterprise bargaining within the confines of their traditional arbitral systems ultimately proved unsustainable, and as a consequence more far-reaching changes ensued in due course.

Second, from the early 1990s, first New Zealand and then Australia took major turns away from their traditional approaches to industrial relations. In New Zealand, a "big bang" legislative reform was effected in a single hit in 1991, whereas in Australia the reform process had to be implemented progressively over a ten-year period. The legal changes implemented by conservative governments in both countries shared a similar ideological pedigree, centred around individualism and the diminution of the role of "third parties" such as unions and industrial tribunals in favour of direct employeremployee relationships. However, the relative long-term impacts upon collectivism have differed in the two countries. The Employment Contracts Act so decimated collective bargaining and unionisation in New Zealand that they have never recovered. However, in Australia, the impact was less severe because the longevity of the Work Choices legislation was more limited and the essentially collectivist awards system survived.

Third, the reforms introduced by Labor/Labour governments in each country, seeking to resuscitate unions and collective bargaining after the respective deregulatory experiments, were only limited forms of re-collectivisation. Both the Employment Relations Act and the Fair Work Act provide a platform that is about facilitating collective bargaining - a limited (and arguably insufficient) form of state intervention that does not adequately address employer hostility and antiunion tactics. In both countries, state neutrality as to collective bargaining remains the dominant paradigm and (as Gordon Anderson has observed) "a union, if it is to bargain successfully, is required to fall back on its own strengths" and compete "in the membership marketplace". ${ }^{84}$ Lacking a bolder commitment to collective bargaining through more supportive "default rules", 85 union membership and collective bargaining has declined further in both Australia and New Zealand.

Fourth, contrary to the title of our article, we can see little evidence of deliberate "reaching across the ditch" in the process of collective labour law reform in the two countries over the last 30 years.

84 Anderson Reconstructing New Zealand's Labour Law, above n 4, at 141.

85 See Sachs, above n 3; and Mark Harcourt and others "A Union Default: A Policy to Raise Union Membership, Promote the Freedom to Associate, Protect the Freedom Not to Associate and Progress Union Representation" (2019) 48 ILJ 66. 
Apart from the clear influence of New Zealand's Employment Contracts Act on drastic deregulatory reforms in two Australian states in the early 1990s, ${ }^{86}$ and the reform aspirations of the Australian "New Right", what we mostly see is the implementation of similar concepts such as protected industrial action but without direct or intentional borrowing. It is likely that each country has looked further afield, to North America and the United Kingdom, in implementing reforms such as good faith bargaining and (in Australia's case) a majoritarian-based equivalent of union recognition for bargaining purposes.

Finally, it is also apparent that neither country has been willing to stand still when it comes to the regulatory settings pertaining to collective bargaining. Unions and employers continue to advocate for change, and the reform process in both countries is ongoing. ${ }^{87}$ In a recent reflection on the state of New Zealand labour law, Gordon Anderson reiterated the importance of collective labour laws to the nature of the democracy and society in which we live, noting that: ${ }^{88}$

... a society involving participative voice and reasonable equality is much more likely to be achieved through the joint regulation of employment where workers have a voice in the conditions under which they labour and in the distribution of the wealth created by their labour.

He observed that one of the core requirements in the achievement of that goal is "to effectively enhance and promote collective bargaining". ${ }^{89}$ Those responsible for reform in each country would do well to take his advice.

86 See $\mathrm{n} 2$ and associated text.

87 See Alison Pennington Workplace Policy Reform in New Zealand: What are the Lessons for Australia? (The Australia Institute and the Centre for Future Work, March 2019).

88 Gordon Anderson "Competing Visions and the Transformation of New Zealand Labour Law" in Gordon Anderson and others (eds) Transforming Workplace Relations in New Zealand 1976-2016 (Victoria University Press, Wellington, 2017) 191 at 207.

89 At 208 (emphasis added). 
